\title{
UNIVERSITYOF
}

FORWARD

THINKING

WESTMINSTER用

WestminsterResearch

http://www.westminster.ac.uk/westminsterresearch

Heterogeneity and Vulnerability in the Urban Informal Economy

Dasgupta, N. and Lloyd-Jones, T.

NOTICE: this is the authors' version of a work that was accepted for publication in World Development Perspectives. Changes resulting from the publishing process, such as peer review, editing, corrections, structural formatting, and other quality control mechanisms may not be reflected in this document. Changes may have been made to this work since it was submitted for publication. A definitive version was subsequently published in World Development Perspectives, 10-12, pp. 64-72, 2018.

The final definitive version in World Development Perspectives is available online at:

https://dx.doi.org/10.1016/j.wdp.2018.09.008

(C) 2018. This manuscript version is made available under the CC-BY-NC-ND 4.0 license https://creativecommons.org/licenses/by-nc-nd/4.0/

The WestminsterResearch online digital archive at the University of Westminster aims to make the research output of the University available to a wider audience. Copyright and Moral Rights remain with the authors and/or copyright owners.

Whilst further distribution of specific materials from within this archive is forbidden, you may freely distribute the URL of WestminsterResearch: ((http://westminsterresearch.wmin.ac.uk/)).

In case of abuse or copyright appearing without permission e-mail repository@westminster.ac.uk 


\begin{abstract}
The focus of this paper is on the low-value urban informal economy in sub-Saharan Africa. The paper presents a case study from Uganda, with the focus on secondary cities where much of the urban population growth is expected in the next decade. There is also good evidence that informality will persist within both dynamic and in slow urban economies in sub-Saharan Africa. Analysis of the results from fieldwork is presented in support of the basic argument that, as the informal economy is likely to persist there is need for a more conducive policy approach to ensure its positive contribution to the urban economic development; seen as a mainstay of Africa's future economic development. Currently, the informal economy is considered ephemeral, with little institutional engagement, with the focus on restrictive measures.
\end{abstract}

The paper explores the range of theoretical perspectives on the urban informal economy leading to its re-conceptualizing as part of a continuum of activities in which both formal and informal elements are interlinked. Given the need to improve productivity of activities of different constituent groups along the continuum, the aim of this paper is to develop a conceptual framework that would enable the systematic analyses and identification of the internal diversities within the informal economy. It could be used in future policy research to identify diagnostic groups for entry points. The findings from the fieldwork carried out in the cities of Mbale and Mbarara, show that there are several viable options for sustainable livelihoods, particularly in a dynamic urban center. However, while women dominate in numbers, men remain the main actors. This calls for an inclusive, gender-mainstreamed, propoor development policy to complement an enterprise-based approach.

Key Words: informal economy; earnings gap; micro-enterprise; Uganda. Word count: 268 


\section{Heterogeneity and Vulnerability in the Urban Informal Economy: Reworking the problem in the current context. The case of Uganda}

(Word count 5,200)

\section{Context}

Current trends indicate that most African economies are unlikely to generate sufficient productive jobs to accommodate the expected significant urban population increases through structural changes and modernization. ${ }^{1}$ According to the African Development Bank, the informal economy accounts for 55\% of the GDP in Sub-Saharan Africa and $80 \%$ of its labor force (AfDB, 2013); in Uganda, it contributes 43\% to the total economy (UBOS, 2012). This paper focuses on the rapid increase in recent decades of this low-value urban informal economy in sub-Saharan Africa, drawing on research in Uganda as a case study selected by DFID (UNOPS, 2015). ${ }^{2}$

Within the wider theoretical debate on the informal economy and its role in the larger urban economy, this paper presents the findings of the Uganda case, study which focused on secondary cities where much of the urban growth is expected in the next decade. The basic argument of this paper is that, given the evidence that the informal economy is likely to persist, there is need for a more conducive policy approach to its activities. This would ensure its positive contribution to the urban economy, increasingly recognized as a mainstay of Africa's future economic development.

This leads to the basic proposition of this research, that one very important pathway to inclusive and effective development is through positive support given to the informal economy. There has been no dearth of research and small-scale initiatives on how best to assist these generally low-value activities and the vulnerable groups who participate in them. However, the heterogeneity of the informal economy has posed challenges to developing a systematic approach to unpacking its diversity and to develop appropriate policy responses. 
The aim of this paper is to propose a conceptual framework that systematically analyses the internal diversity within the informal economy. This framework could be used for research seeking to identify diagnostic groups and policy entry points. This conceptualization grew out of empirical research carried out in spring 2016 by an interdisciplinary team. ${ }^{3}$ A summary analysis of the results is presented here in support of the basic argument.

The structure of the paper is as follows: Sections 2 to 3 explore the range of theoretical perspectives on the informal economy leading to its reconceptualization (Section 4) as part of a continuum of activities in which both formal and informal elements are interlinked. This is further supported by theoretical and empirical evidence that informality will persist within the urban economy. Section 5 discusses the notions of heterogeneity and section 6 sets out the analytical model developed to unpack this internal diversity. Section 7 concludes the paper.

The methodology and the detailed discussions of the primary research in the secondary Ugandan cities of Mbale and Mbarara and of the analyses are described in full in Chapter 5 of Lloyd-Jones, et al (2016).

\section{Perspectives on Informality}

This research has taken the definitions of the informal sector and informal economy developed by ILO (2003) as a starting point. According to the ILO, the 'informal sector' refers to informal enterprises, while 'informal employment' refers to informal jobs specifically own account workers, employees and employers, contributing family members and members of producers' cooperatives working in informal enterprises. The 'informal economy' includes, additional to those employed in informal enterprises, persons in informal employment within the formal sector; more specifically: "employees in formal enterprises not covered by social protection through their work; paid domestic workers not covered by social protection through their work; and contributing family workers working in formal 
enterprises" (WIEGO, 2012). Conventionally, the informal sector includes those enterprises that are not registered with the local government. The 2012/13 Uganda National Household Survey report (UBOS, 2014) includes the following wider definition for employment in the non-agricultural informal sector:

- Employees in establishments with less than 5 employees; and

- Employers, own account workers and unpaid persons in household businesses not registered for income tax or value added tax.

This study focused on easily identified informal enterprises. However, although synonymous with the informal sector as defined by the ILO, the more general term informal economy was preferred. In the theoretical perspective of an economic continuum adopted by the study, it was more accurate to refer to 'informal economic sectors', as components in the informal economy at the lower end of the spectrum of urban economic activity and associated with economic sectors classified within what is conventionally understood as the formal economy.

Even after many decades, informality continues to attract an array of views and often opposing approaches to analysis, each with their own policy prescription. As Chen (2007) notes, the increase in interest in informality, however viewed, is a tacit recognition of its persistence, and recognition that it is not simply a short-term feature of developing economies. Crucially though, some policy makers in Africa, still strongly influenced by the dualistic notions of the formal/informal and modernization models of 1960-70s, expect the informal economy to disappear with economic growth. As Meagher (2001) notes "dualism... was the bane of informal sector."

In the context of developing economies, there are two strongly identifiable perspectives on informality in the current debate. The first is the neo-liberal view, as critiqued by Moser (1994) and Rakowski, (1994), lodged in a dualistic model which still stigmatizes the informal 
activities as illegal, one that lowers growth and productivity and which entrenches corruption (Farrell, 2004; Schneider \& Enst, 2000; Loayza, 1997). The key distinction here is between 'legal' and 'illegal' activities, the latter trying to evade taxation or failing to comply with the state regulations. The consequent (mainstream) view is that this 'shadow economy' should be controlled by strengthening enforcement. An alternative neoliberal view of informal activities, still viewed through a binary lens but more open to a sympathetic policy response, presents it as a rational response to excessive state regulations. For example, De Soto (1989), from a legalistic perspective, suggested that the correct policy response should be greater support to micro-enterprises.

The further perspective, embodying a structuralist approach, but again framed by dualism and further reinforced by modernization theories (Potts, 2008), positions informality as integral to capitalist development and its inability to absorb the unemployed. Taking this argument further, it was argued that the informal economy would shrink with economic growth and structural transformation. However, the key issue in Africa, is that there has been continuing growth, but in a form not associated with structural change, transformation and employment creation to the degree required to absorb all those currently un- and underemployed. The evidence from this study indicates that informality persists and, to some degree, thrives in both slow-growing urban economies and in dynamic urban centers. This underscores the importance of supporting the development of the informal economy in more positive manner than hitherto.

Leading on from this perspective, and following Chen (2012), this paper argues the need to move away from the pre-occupation with cleavages within the urban economy and towards a conceptualization of informal activities as part of a continuum of economic activities. This continuum is characterized by relatively high productivity and product sophistication at the higher end, and by low productivity and more basic products and services at the lower end of 
the continuum. As noted, the urban economy in African cities is currently dominated by informality and in better viewed as a hybrid of formal and informal activities (Lloyd-Jones, et al 2016). If it is to be boosted, the urban economic continuum as a whole must be strengthened. Productivity improvements for many of the activities located in the lower half of this continuum, this paper argues, could be achieved through targeted policy interventions.

\section{Informality as an integral part of the current urban economic continuum}

The dualistic approach has contributed to an increased understanding of informality, but allied with the conviction that it would disappear with economic growth. This conviction has been taken to imply that there is little governments can or should do to directly assist the informal economy, with action limited to registering firms and aiming to tax them without offering any particular economic or social benefits in return. The research undertaken in Uganda indicated that this trend is further exacerbated by donor emphasis on improved fiscal management and local government revenue generation.

The payment of fees or taxes is also often used as the basis for the divide between formal and informal. The fieldwork shows, that while the informal units studied do not pay tax, all the so called 'unregistered' business units, whatever their size, pay rent in the form of a fee to the local 'tenderer' (who has access to the use of public land); and pay protection money.

Another associated common strategy in Africa to approach informality is large-scale and/or sporadic eviction of informal enterprises. Tibaijuka (2005) reported on mass eviction in Zimbabwe; Potts (2007) in Harare; and King (2006 as cited in Skinner, 2008, p. 9) noted, that in the Ghanaian context, frequent changes in local authorities lead to evictions of street traders, which is seen as "a common way to impress the public." Similarly, in the Asian context, Dasgupta (1992b) noted mass evictions or 'clearing of street' in Kolkata with every change of government. In Kampala, in this study, street traders noted that they are regularly 
evicted and then allowed back on 'payment'. Apart from the temptation to use such practices for extortion at the street level, there is little interest in poverty reduction and social development, but a pre-occupation with physical planning and increasing the tax base. This approach fails to distinguish between legitimate activities of the poor and vulnerable, from the tax avoidance activities of some.

Since the informal economy is considered ephemeral, the African policy community continues to largely ignore it, with hardly any institutional engagement at the national or at lower levels. Page (2015) notes that the single most important contribution in Africa would be the recognition of this vast reservoir of low paid jobs. A review of the policy documents in Uganda shows that the informal economy is largely invisible in the national, local and urban planning agenda. For instance, Uganda Vision 2040 (GoU, 2014) has no reference to informal activities. This policy neglect has been attributed to Uganda's political economy with a small, elitist policy community dominating policy-making. Tanaka (2010), for example, argued that this community rarely values the resources and skills of the informal sector while it continues to exploit it. This indifference extends to research and institutions. Moreno-Monroy (2012, p. 2019) notes that in urban economics literature "informal economy, if mentioned at all, is a side issue."

All theoretical interpretations of the informal economy accept that it is an important economic space for the poor, the vulnerable and the unemployed. These include, Hart (1971) and ILO in $(1972)^{4}$; the two-circuit system of Santos (1971); the two juxtaposed systems of production by McGee $(1971,1967)$ and the Marxist analysis of capitalist mode of production exploiting the pre-capitalist petty commodity sector (Laclau, 1971; Moser, 1994). Dependency theorist (Cardoso, 1972; Frank, 1969) argued that such dichotomous growth was inevitable in a capitalist system and emphasized the exploitative nature of the formalinformal relationships, but offered few policy options. 
An argument of this paper is that the informal economy remains an important entry point into the urban economy for the poor, and for those with limited alternatives and resources. However, some of the dynamics affecting informality are now additionally conditioned by the recent trends where there is continuing economic growth, but not in the form to bring structural change and decent employment creation.

Further, Chen (2007) argues that the informal economy cannot be viewed as marginal or peripheral, but as a basic component of the total economy. Thus, the informal economy is complex and cannot be analyzed using linear and dualistic models. This argument is based on evidence that informality is also a feature of the modern capitalist system as it continues to grow both with economic slowdown; but also with rapid economic growth.

Evidence from Africa shows that the slow pace of industrialization is moving labor from high-productivity sectors to low productivity sectors. McMillan and Rodrik (2011) argue that large gaps in labor productivity between the traditional and modern parts of the economy are the fundamental realities of developing societies, and that labor flows from low-productivity activities to high-productivity activities are the key drivers of development. Their research indicates that since 1990 structural changes have resulted in labor moving from low- to highproductivity sectors in Asia, but mainly in the opposite direction in Latin America and subSaharan Africa. World Bank (1999) put forward the 'premature urbanization thesis' or overurbanization. It notes that, in the period leading up to the earlier years of this century, rapid urbanization in many sub-Saharan countries appears to have taken place without economic growth over a prolonged period of three decades, contributing to the growth of the low value informal economy. This thesis on the disconnection between urbanization and economic growth has generated much continuing debate and controversy (Fay and Opal, 2000). 
On the other hand, the case of India shows that growth in modern industrial activities has increased the extent and dynamism of the informal manufacturing units. After reviewing the performance of informal manufacturing units in terms of growth, increased productivity and dynamism, in the context of pre-reform and post-reform periods, Mukherjee (2009) argued that informal activities could be the next engine of growth for the Indian economy.

According to Chambwera et al. (2011) India's macro-economic growth (with a growth rate of around $6.5 \%$ for much of the last decade) does not translate into shrinking the informal economy. In 2004-05, the informal sector accounted for $93 \%$ of total employment including agriculture and $82.4 \%$ of employment in non-agricultural economic activities, as per the National Sample Survey Organisation (NSSO, 2006). The informal activities accounted for almost 50\% of India's GDP in 2007-08 (Sen and Kolli, 2009).

This research ${ }^{1}$ in Uganda indicates that Mbarara (Figure 1), with a fast-growing modern industrial sector, has a bigger informal economy than Mbale, an economically stagnating administrative center (the population of Mbarara is double that of Mbale; but identified street trading is three times more numerous than in Mbale).

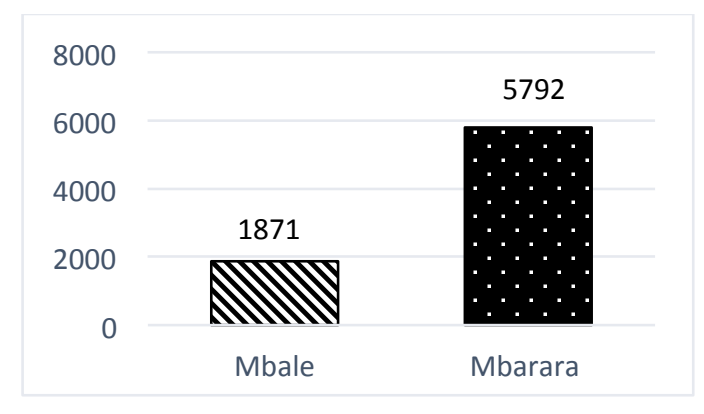

Figure 1: Estimated No of street trading units

From a dualistic perspective, the informal economy should be shrinking in Mbarara and growing in Mbale. However, the dynamic relationship between economic growth and the informal economy in Mbarara appears to be subject to positive feedback. A multiplier effect

\footnotetext{
${ }^{1}$ The analysis here is based on in-depth primary research in Mbale and Mbarara, see Lloyd-Jones et al (2016), Chapter 5 .
} 
associated with the expansion of large-scale industrial activity creating new jobs, would be expected to increase the demand for goods and services at all levels of the urban economic continuum, with such demand becoming a source of livelihood for many different groups operating in different informal sectors. Technology-intensive, modern industrial growth (Evan, 2008; Lucas, 1988; Negroponte, 1996; Romer, 1990) creates only a limited number of jobs, but the expectation of employment can attract a large pool of migrant job seekers who find themselves unemployed. They join the "survivalists" (Hart, 1971; ILO, 1972; Rogerson, 1996); Todaro's (1969) rural-urban migrants (who do not necessarily move on) and the entrepreneurs to meet the increased demand for goods and services in the lower end of the urban continuum, thereby, expanding the informal economy. It is important to stress that some participate by choice (Hart: 1971). In Uganda, it is the entrepreneurs at the upper end of informality with resources and business network links, while at the lower end it the shoeseller of Arua, discussed below in Section $4 .^{2}$

Furthermore, even a sub-sector of an economy does not grow if it does not provide viable livelihood options. As De Soto (1989) argued, all participants in such small enterprises are making a rational choice for their given level of resource in terms of education, skill, capital, 'who you know' and market knowledge among others. Taking this argument further, it would be a rational choice only if it enables a viable income at their level of resource.

Figure 2 underscores the basic argument of this paper that informality in a dynamic urban economy is stronger, provides more viable income options and supports a large population (Fig 1). On the other hand, it also supports Hulme's (2003) chronic poor and transient poor. The survey of informal operators in the case study cities indicate these groups represent $12 \%$ and $36 \%$ of the total respectively in Mbale; and 3\% and $10 \%$ in Mbarara. Figure 2 also encapsulates the income-poverty-risk relationships of different gender groups. Policies to

\footnotetext{
${ }^{2}$ Lloyd-Jones et al (2016) Figure 5.3.
} 
suppress, ignore or stigmatize the informal economy will further exacerbate the vulnerabilities of the poorest groups.

Figure 2: Viability of Informal Activities: Estimated Income Distribution in Street Trading

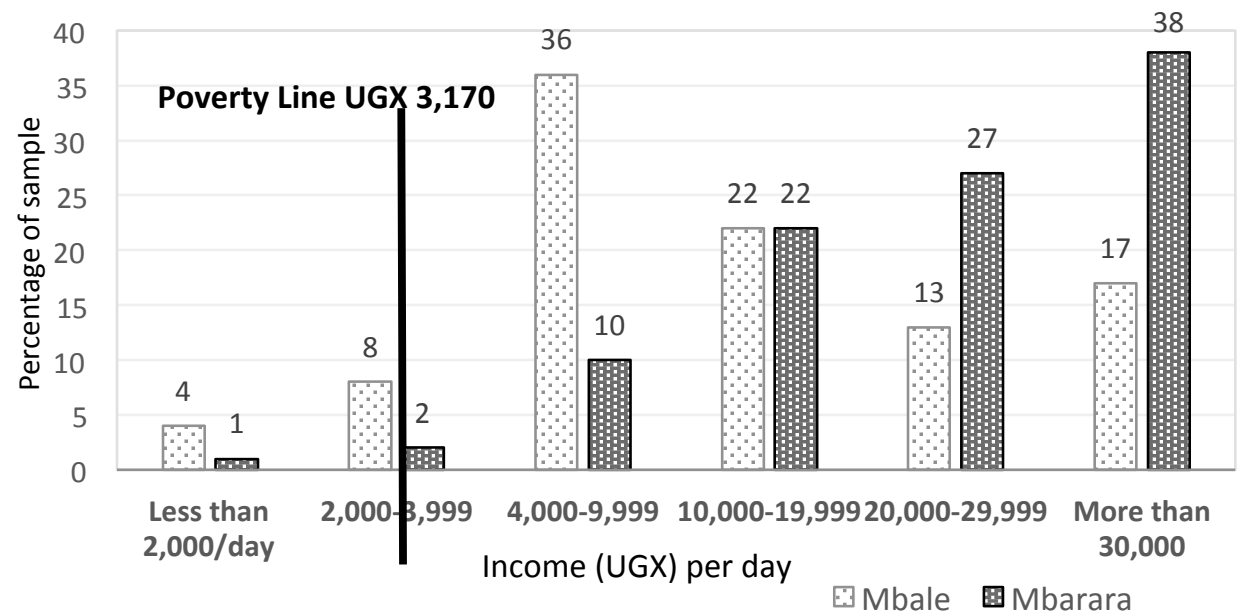

Mbale: (UGX)

Sample Mean: 14,544

Men: 16,848

Women: 12,136

Mbarara: (UGX)

Sample Mean: 22,375

Men: 20,970

Women: 22,050

\section{Re-conceptualizing informality}

Chen (Ibid) notes that the two ends of the urban continuum are often dynamically linked. Linkages cutting across the formal and informal economies at individual and sub-sector levels and value chains stretch across the urban economic continuum. This is supported by Valodia and Devey (2012), exploring the linkages between the formal and informal economy in South Africa. They conclude that there is a high level of interaction between formal and informal work even at the lower end of the labor market. At the household level, too, access to stable employment in the formal economy is associated with higher levels of earning in the informal economy.

Mitullah et al. (2013) argue that dualism is not a relevant distinction as individuals work across the spectrum depending where employment and enterprise opportunities are available. The initial participatory survey undertaken shows that in Arua individual traders, like the 
shoe-seller, who purchase second-hand items from wholesalers in Kampala, sell it to customers in Arua who are working in the formal sector (e.g., civil servants) and to those working in the informal economy. In Mbarara, informal brick-makers are the main source of bricks for modern housing and commercial buildings, as well as for informal housing. Bigstein and Kayizzi's (1992) work in Kampala revealed government officials engaged in urban agriculture and other informal activities.

All this implies that linkages that exist along the continuum can take various forms (Chen, Ibid). These can be as (i) individual transactions: Where informal enterprises exchange goods and services with formal enterprises where the more competitive firms control the transaction; (ii) sub-sector of units which produce/process goods to distribute and sell to customers from both formal and informal economies; and (iii) informal units which are part of a value chain stretching across the continuum. This would include groups, as seen in Mbale, who collect waste plastic, metal and other recyclables to sell to a local middleman, who grades and segregates the waste, who then sells to the regional trader, who ultimately sells to the recycling plant located outside Mbale.

ILO (2003) in an amendment to its earlier dualistic view, has tried to broaden the concept to an emphasis on a continuum of employment and production relations. However, its central interest remains employment relations. Chen $(2007 ; 2012)$ argues that it is not only a continuum for employment relations, but that the informal economy is part of a continuum of economic relations of production, distribution and employment. Here the entrepreneurs and workers, depending on their circumstances, move with varying speed and ease along the continuum, and operate simultaneously at different points in the continuum.

The implications of these arguments for this study are that within each sphere of activity (horizontal segmentation) which could stretch across the urban continuum, there are cross- 
cutting socio-economic and demographic factors, intersecting with a variety of production and employment relations (vertical heterogeneity) creating multiple diagnostic groups. Each of these groups will reflect different forms of societal, household and individual vulnerabilities and strengths and policy needs.

\section{The need to address heterogeneity}

Heterogeneity is the most defining character of an informal economy that embodies and reflects different forms of societal vulnerabilities in the context of the current processes of urbanization and economic growth based on technology intensive industrialization. Thus, understanding these factors, linkages and relationships behind the internal diversity of the informal economy has now become essential for developing policy options. However, the implications of this internal diversity, is that there is no single urban governance and economic approach to the informal economy.

Conceptually, heterogeneity has two dimensions as noted: vertical and horizontal. The socioeconomic differentiations that exist in terms of income, poverty-risk and vulnerability give rise to vertical heterogeneity. This emerges as different groups engage with the urban economy in a way that is most beneficial to them and one that allows them to develop a portfolio of activities. Furthermore, this heterogeneity occurs because the strategies adopted are seen to vary with socio-demographic group, and within each such group with gender, age, education and location (Lloyd-Jones et al, 2016).

ILO $(2003 ; 2015)$ with its focus on employment, has tried to analyze and systemize the labor market aspect of informal activities. While studies (Bromley, 1978a, 1978b and 1985; Bunster, 1983; Dasgupta, 1992a; Moser \& Marsie-Hazen, 1984) have referred to a variety of production and employment relations, there has been limited systematic approach to unbundling and structuring these relations. WIEGO (2012) and (Chen 2007) developed a 
hierarchical, conceptual model (reflecting the vertical heterogeneity), a pyramid, to locate and relate income, poverty-risk and vulnerability, by gender, which this study builds on and is discussed below.

The other dimension is the horizontal heterogeneity attributed to the variety of activities within the informal economy. Studies have distinguished informal business sectors (waste picking; garment piece making; street trading, brick-making, etc.) and have then built up a picture of production's relations existing in that sector. Heterogeneity has been well documented by theorists of different perspectives (dualistic, structuralist, legalist). This has been done in singular terms of income, gender, size of units, types of entrepreneurs, type of work, place of work, among others.

The two dimensions cannot be studied in isolation of each other. It is important to analyze the cross-cutting nature of the diversity that has created different diagnostic groups. These should be identified, understood and policy needs recognized and addressed. While several policy options are already available, a conceptual framework for identifying such groups is needed to link policy to needs of chronic poor and of the successful entrepreneur. Identifying the latter group will be crucial to improving productivity along the urban continuum. The proposed conceptual framework therefore focuses on the people who populate the informal economy rather than the enterprise per se.

This is important as studies ${ }^{5}$ by (Grimm et al, 2011) and Nutz and Sievers (2015) in subSaharan Africa; (Lince, 2011) in Uganda and Nnkya's (2002) in Dar-es-Salaam have shown that those more vulnerable (i.e. those who need help most) tend to lose out as they are unable to participate in development programs. At the lower end of the continuum, it is crucial to understand informal activities as part of the entrepreneur's portfolio of livelihood strategies to develop effective ways to enhance productivity and add value. Although this paper does not 
detract from the importance of this business unit-based approach, it argues that it must be supported by a "people-centered approach" (Rakodi and Lloyd-Jones, 2002) to complement it, if poverty-reduction and inclusive development are the main policy objectives. As Collier (2015, p. 2) notes, a focus only on productivity can lead to a "tragedy of squalid living conditions."

Heterogeneity in Uganda: The need to unpack and understand the groups created by the cross-cutting dimensions of horizontal and vertical heterogeneity is further reinforced by the current evidence from Uganda. It has been demonstrated that informality is getting increasingly diverse in terms of socio-demography. It is providing viable livelihood options for individuals with many different levels of resources and skills. It is supplying a wide variety of goods and services, the particularly so in Mbarara, where the modern, technologyintensive industries are being increasingly concentrated. ${ }^{3}$ However, the gendered perspective taken by this research highlights another layer of diversity and the higher income-risk profiles of women.

In the rest of Africa (Skinner, 2009; ILO, 2015) women dominate street trading. However, according to the case study research, the share of women traders stands at $49 \%$ in Mbale and $64 \%$ in Mbarara. suggesting a need for in-depth analysis. Analyzing the vertical heterogeneity in street trading shows women in Mbale have limited choice, joining low earning activities as they are unable to enter the higher income activities and giving them a low income-high risk profile. On the other hand, in Mbarara, women dominate several activities that enable higher earnings, successfully compete with men and are the dominant traders in cooked food (high earner). They generally incur lower risks, and hence, are less vulnerable than the women in Mbale.

\footnotetext{
${ }^{3}$ Lloyd-Jones et al (2016) Figures 5.8 and 5.9.
} 
Men in both cities dominate activities that require investment and skill, though more so in Mbarara. They sit in the group of high income-low risk. Most men in Mbale are not all that better off than the women.

In general, women suffer the same disadvantages noted in the wider research in terms of investment they can bring to the business; the limited time they can spend on productive work as they try to balance productive and re-productive exigencies; and constrained access to education. However, a key difference is that a large number of women in Mbarara are competitive as they bring investments equivalent to men. Women's investments are higher Mbarara than Mbale. ${ }^{4}$

Nevertheless, as noted, the high income-low risk informal economy in Mbarara is dominated by younger men, who spend on average around 7 years before moving on. Women with the same or higher levels of education are unable to move on. This, together with the predominance of women in all educational categories and longer time they spend underscores the disadvantageous position of women and raises questions about the nature of urban economic growth opportunities.

\section{Informality and un-packing heterogeneity - a conceptual framework}

Given the wider economic context, it is argued that the informal economy is becoming progressively more heterogeneous in terms of demographic groups entering the sector, in types of linkages (including many cross linkages to the formal sector) and in the variety of economic enterprises. Whilst the growing heterogeneity makes it economically dynamic, it also limits cohesion and collective representation in urban politics (Brown et al, 2010; Tanaka, 2010).

\footnotetext{
${ }^{4}$ For detailed statistical analysis of investment, education, income, education by gender and age, by city, see Lloyd-Jones et al (2016) Chapter 5.
} 
The informal economy has acted as an, often inadequate, sink for the unemployed, educated young job seekers (Dasgupta, 1992b). Given the macro-economic trends (discussed earlier) this path to urban livelihood creation is of greater importance now as educated youth unemployment rises in Uganda. The 2009-10 Uganda National Household Survey, showed the share of unemployed youth (18-30 year) at $64 \%$ (UBOS, 2010). It would be important to identify the activities attracting these youths.

This paper takes forward the notions developed by Chen (2012) aimed at building a more holistic model of the informal economy, as adapted in Figure 3. However, Chen acknowledges that the impacts of the horizontal segmentation introduced by different types of work are not captured by her generalized model unpacking the vertical heterogeneity. In reality, the diagnostic groups, and the shape and constituency of the pyramid will vary with the sector of activity. This is addressed in the conceptual framework developed through this study. 


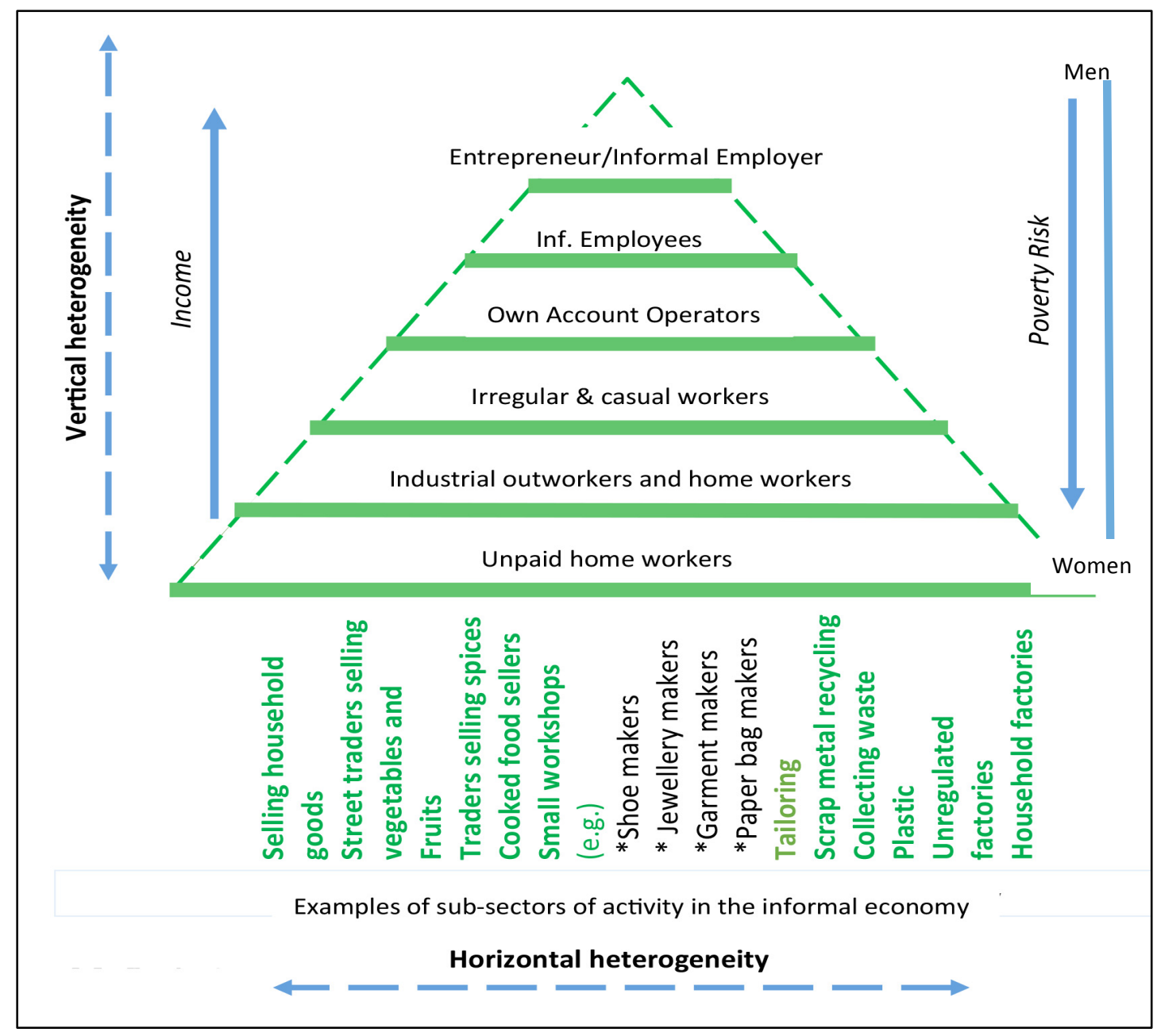

Figure 3: Conceptual Model to Unpack Heterogeneity

The groups shown in each layer of triangle are those identified by Chen. It is contended here that, within each sector of activity, while all categories of income hierarchy may be present, the group sizes will vary by numbers, sex and vulnerability of individuals. It will be essential to capture the three-sided relationship between type of activity, income-poverty, risks and the socio-demography, by identifying different analytical groups.

One of the principal arguments of this paper is that the constituency of the pyramid depicting the socio-demographic and economic heterogeneity vary with the sector of activity. Each 
constituent group will reflect the production and employment relations of the sphere of activity, be it street trading or brick making. ${ }^{5}$ This is illustrated in Figures 4 to 6 .

\section{Figure 4: Mbale: Vertical Heterogeneity in Street Trading}

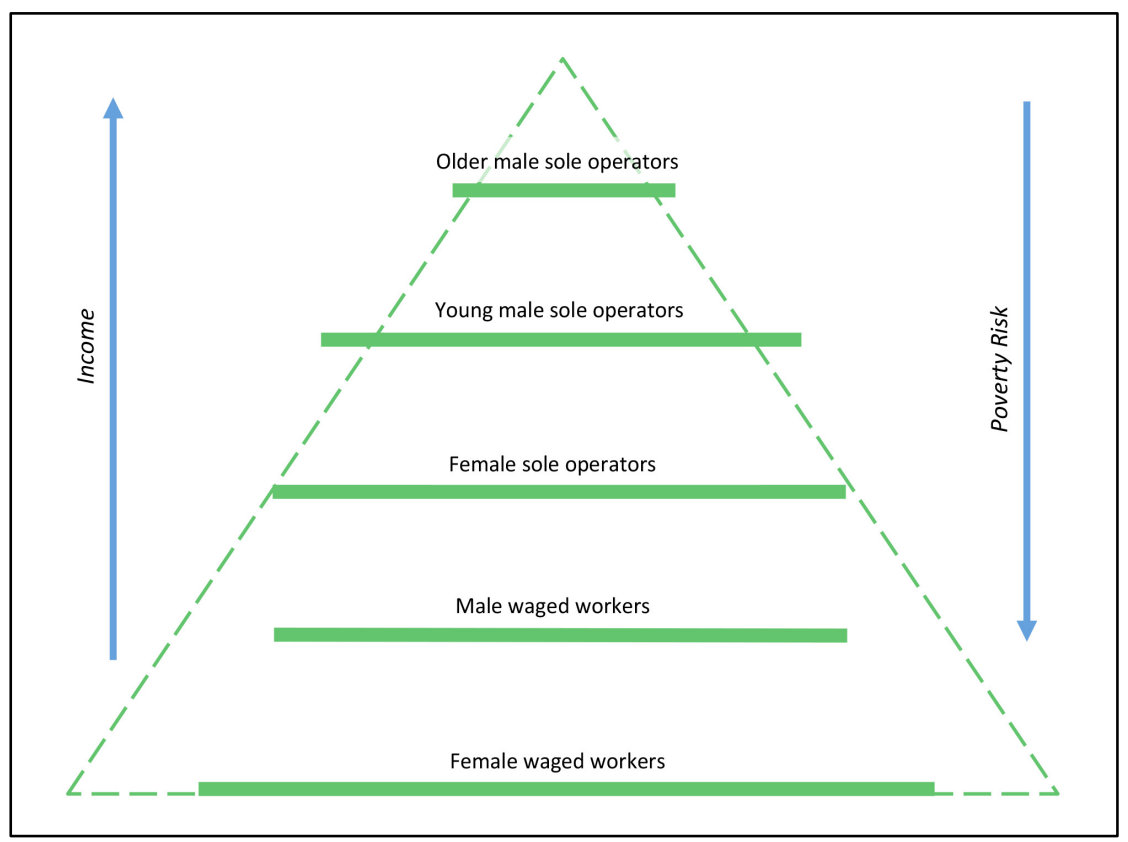

Figure 5 Mbarara: Vertical Heterogeneity in Street Trading

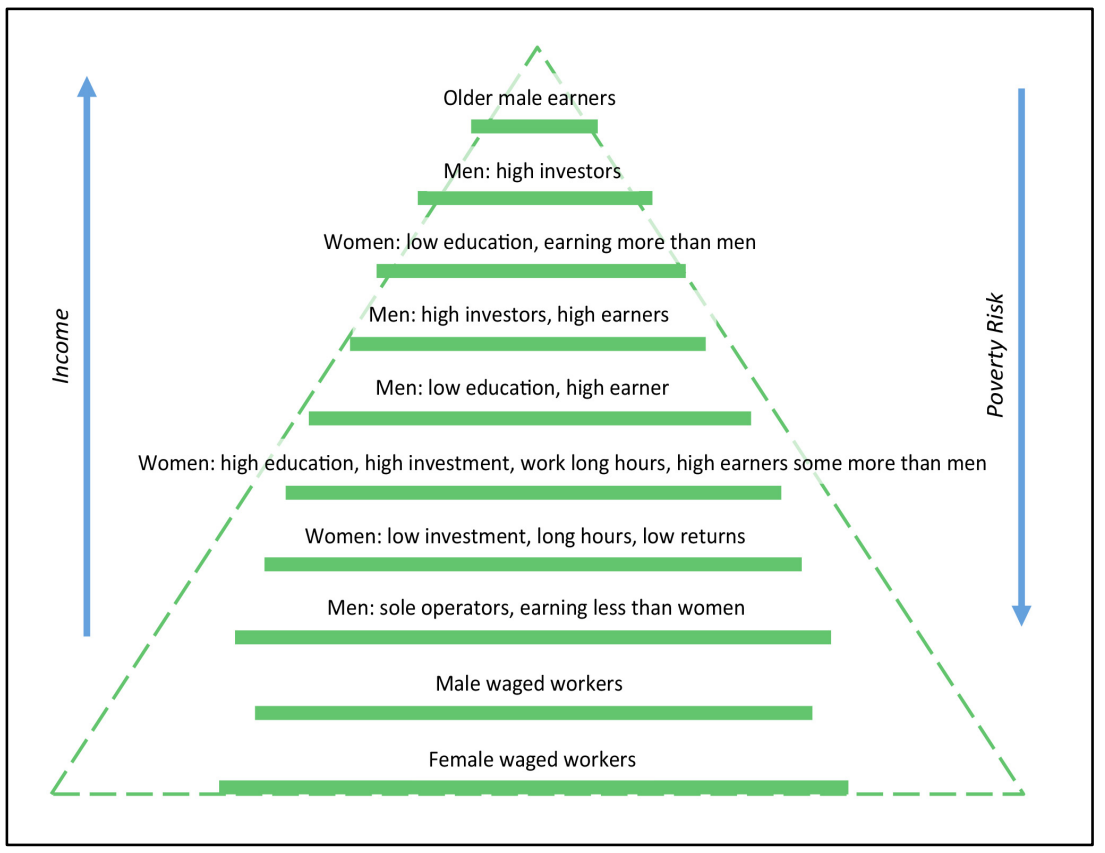

${ }^{5}$ For brief analysis of informal brickmaking, see Lloyd-Jones et al (2016) Chapter 5, p123. 
Figure 6: Vertical Heterogeneity in Brick Making

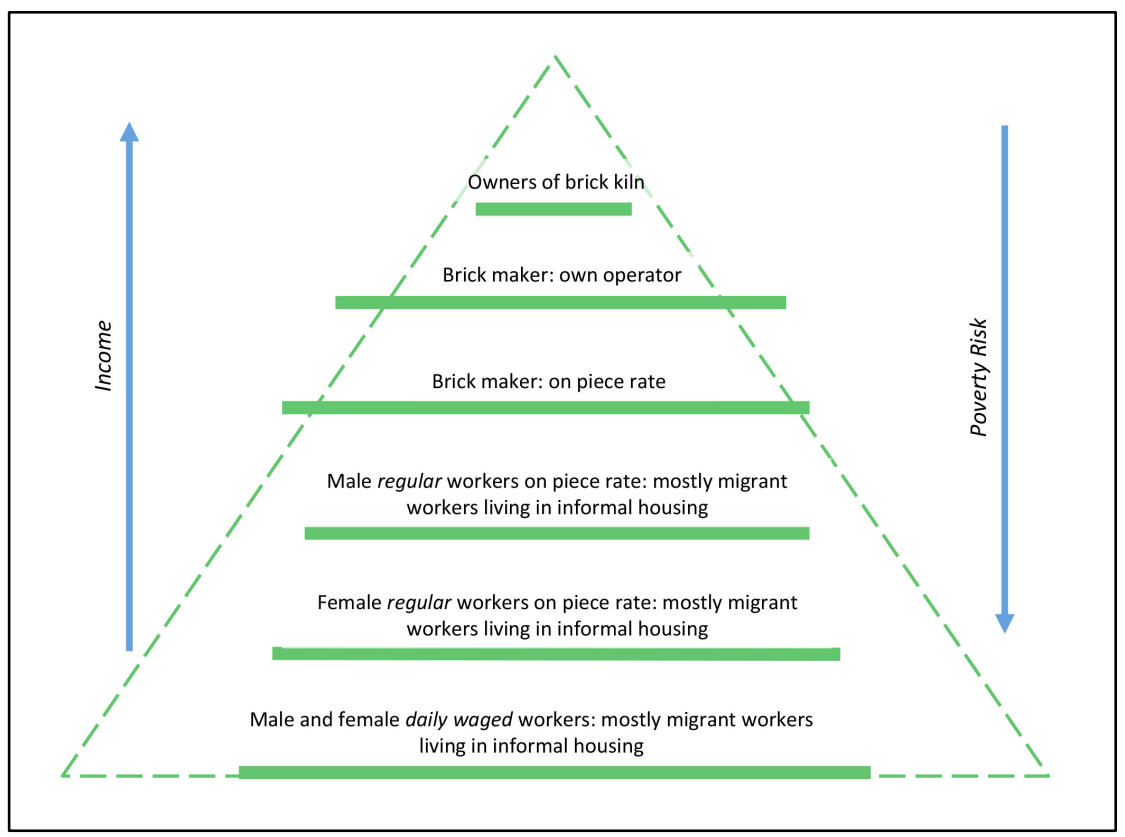

Figure 6 shows that the difference is less gendered than in street trading. However, women tend to lose out, even as wage workers. While men dominate all three pyramids, the different structural constituencies show the highly segmented nature of the informal economy in terms of average earnings and poverty risks, suggesting a nuanced approach is essential.

\section{Conclusions}

At the conceptual level the study lends strong weight to the argument that the informal economy remains an integral part of the urbanization in slow- and fast-growing economies. It is not only a continuum for employment relations, but a part of the economic continuum of production and distribution. Furthermore, technology-intensive industrialization is increasing the diversity within the informal economy, reinforcing heterogeneity as the defining character of informality. This underscores the need to understand this diversity to enable more targeted and informed urban policy making. 


\section{Key findings:}

- The overall economic context (i.e. the nature of growth; slow growth/fast growing) of the urban continuum has considerable and direct impact on the way the informal economy is integrated with the urban economy. The nature of informality and the life chances and opportunities of the small entrepreneurs are conditioned by these dynamics.

- This study shows that informality in the current context is an economic space for far more diverse groups than envisaged by dualists, legalists or structuralists.

- It has been demonstrated that the informal economy in a dynamic urban context is stronger, provides more viable income options and supports a larger population than in a slow growing city.

- The Mbarara case study presented very different dynamics and some raises policy concerns. Women have built viable and lucrative businesses, yet men remain the dominant actors. Women entrepreneurs at similar education level find it even more difficult to exit informality; whereas men avail alternative opportunities more easily. This might suggest that the apparent success of women camouflages the real dynamics of the current economic development, i.e., the wider job market is not easily accessible to women.

- It is important to mainstream gender in urban development and economic growth plans. Both men and women should be equally targeted for capacity and skills development. This would also slow down entry into informality.

- The dis-aggregation of the vertical heterogeneity in street trading and brickmaking shows that while the entrepreneurs at the top of the pyramid in the different sectors can be assisted to move up the urban continuum of productivity, the vulnerable groups forming the base of the pyramid, i.e. the chronic and/or transient poor require a people-centered 
approach to poverty reduction. This becomes all the more important as the collective representation of informality in urban politics in Africa is very limited.

Future research: There is a need for further city-level data collection and analysis including social and demographic group diagnostics. Data and knowledge of the hybrid formalinformal economy is lacking in Uganda and this is not untypical of sub-Saharan Africa.

An improved understanding of the hybrid economy can be achieved through analysis of existing value chains and value network involving formal and informal enterprises have to be better understood.

These findings suggest a need to understand the complexity of livelihood strategies attached to informal economies, the skills and capacities that can be used to engage in effective and mutually-beneficial ways with state actors and subsequently enhance pro poor governance that also benefits the cities. 


\section{References (word count: 1635)}

AfDB (2013) Recognizing Africa's Informal Sector. AfDB, 27 March. In:

http://www.afdb.org/en/blogs/afdb-championing-inclusive-growth-across-Africa/post/recognisinginformal-sector-11645 [Accessed 19 May 2016].

Bigsten, A. and Kayizzi-Mugerwa, S. (1992) Adaption and Distress in the Urban Economy: As study of Kampala Households. World Development 20(10): 1423-1442. doi: 10.1016/0305-750X(92)90064-3.

Bromley, R. (1978a) Introduction to Urban Informal sector, why it is worth discussing? World Development 6 (9/10): 1033-1039. doi: 0.1016/0305-750X(78)90061-X.

Bromley, R. (1978b) Organization, Regulation and Exploitation in the so-called Urban Informal Sector: The Street Traders of Cali, Columbia. World Development 6 (9/10): 11611171. doi: 10.1016/0305-750X(78)90070-0.

Bromley, R. (1985) Planning for Small Enterprises in the Third World Cities. Oxford: Pergamon Press.

Brown, A., Lyon. M and Dankoco, I. (2010) Street Traders and Emerging Spaces of Urban Voice and Citizenship in African Cities. Urban Studies Journal 47(3): 666-683. doi: $10.1177 / 0042098009351187$.

Bunster, B.X. (1983) Market Sellers in Lima, Peru: Talking about work. In Bunvinic, M. (Ed) Women and Poverty in the Third World. Johns Hopkin University Press.

Cardoso, F.H. (1972) Dependency and Development in Latin America. New Left Review 74 (July-August). 
Chambwera, M., MacGregor, J. and Baker, A. (2011) The Informal Economy. A primer for development professionals on the importance of the informal economy in developing countries, sustainable markets. London: IIED.

Chen, M.A. (2012) The Informal Economy: Definitions, Theories and Policies. WEIGO Working Paper No 1, August. Harvard: WIEGO.

Chen, M.A. (2007) Rethinking the Informal Economy: Linkages with the Formal Economy and Formal Regulatory Environment. DST/ESA/2007/DWP/46ESA Working Paper No 46. NY: UN DESA.

Cleland, J, and Machiyama, K (2016) The Challenges Posed by Demographic Change in sub Saharan Africa: A Concise Overview, Population and Development Review, Vol 43, Issue S1. https://onlinelibrary.wiley.com/toc/17284457/43/S1

Collier (2015) African Urbanisation: An Analytical Policy Guide. UK: The International Growth Centre. In: https:/www.theigc.org/wp-content/uploads/2016/01/AfricanUrbanizationJan2016_Collier_Formatted-1.pdf.

Dasgupta, N. (1992a) Petty Trading in the Third World City: The case of Calcutta. Avebury, UK.

Dasgupta, N. (1992b) Linkage, Heterogeneity and Income Determinants in Petty Trading: The Case of Calcutta. World Development 20(10): 1391-1546. doi: 10.1016/0305750X(92)90065-4.

De Soto, H. (1989) The other Path: The Informal Revolution. New York: Harper and Row. 
Evan, P.B. (2008) In Search of $21^{\text {st }}$ Century Developmental State. Centre for Global Political Economy, Working Paper No 4. Sussex: CGPE, University of Sussex. In: https://www.sussex.ac.uk/webteam/gateway/file.php?name=cgpe-wp04-peterevans.pdf\&site $=359$.

Farrell, D. (2004) The Hidden Dangers of the Informal Economy. The McKinsey Quarterly, 3.

Fay, M. and Opal, C. (2000) Urbanization without growth: A not so uncommon phenomenon. Policy Research Working Paper, No. 2412. Washington DC: World Bank Publications. In: https://openknowledge.worldbank.org/handle/10986/21373 License: CC BY 3.0 IGO.

Frank, A.G. (1972) Lumpen Bourgeoisie, Lumpen Development. London: The Macmillan Press.

Government of Uganda (2014) Vision 2040. Kampala: Ministry of Finance, Planning and Economic Development. In: http://npa.ug/wpcontent/themes/npatheme/documents/vision2040.pdf.

Government of Jordan (2014) The Jordan National Employment-Technical and Vocational Education and Training (E-TVET) Strategy. Jordan: National E-TVET Council. In: http://inform.gov.jo/LinkClick.aspx?fileticket=zRBuaLn6gRg\%3D\&portalid=0\&language=e n-US.

Grimm, M, Knorringa, P. and Lay, J. (2012) Constrained Gazelles: High Potential in West Africa’s Informal Economy. World Development 40(7): 1352-1368. doi:

10.1016/j.worlddev.2012.03.009. 
Grimm, M, Van der Hoeven, R. and Lay, J. (2011) Unlocking potential: tackling economic, institutional and social constraints of informal entrepreneurship in Sub-Saharan Africa: main findings and policy conclusions. Washington DC: World Bank. In: http://documents.worldbank.org/curated/en/895161468337243229/Unlocking-potentialtackling-economic-institutional-and-social-constraints-of-informal-entrepreneurship-in-SubSaharan-Africa-main-findings-and-policy-conclusions

Hart, K. (1971) Employment, Income and equality: A strategy for increasing employment in Kenya. Geneva: ILO.

Hulme, D. (2003) Conceptualising Chronic Poverty. World Development 31(3): 403-423. doi: 10.1016/S0305-750X(02)00222-X.

Ikoja-Odongo, R. (2002) The Insights into the Information Needs of Women in the Informal Sector of Uganda. South African Journal of Libraries and Information Science 68(1): 39-61. doi: http://dx.doi.org/10.7553/68-1-765.

ILO (1972) Employment, Incomes and Inequalities: A strategy for increasing Productive employment in Kenya. Geneva: ILO.

ILO (2003) Defining and measuring Informal Employment. Geneva: ILO.

ILO (2015) The Transition from the Informal to the Formal Economy-ILC 2015. Proceedings of the conference, $104^{\text {th }}$ Session. June 2015 Johnston-Anumonwo, I. and Doane, D.L. (2011) Globalisation, Economic Crisis and Africa's Informal Economy Women Workers. Singapore Journal of Tropical Geography 32: 8-21. doi: 10.1111/j.1467-9493.2011.00416.x 
King, R. (2006) Fulcrum of the Urban Economy: Governance and Street Livelihoods in Kumasi, Ghana. In Brown, A. (ed.) Contested Space: Street Trading, Public Space, and Livelihoods in Developing Cities. Warwickshire: Intermediate Technology Publications. Laclau, E. (1971) Feudalism and Capitalism in Latin America. New Left Review. May-June. Ligthelm, A. (2006) Size and Estimates of the informal sector in South Africa. Southern African Business Review 10(2): 32-52.

Lince, S (2011) The Informal Sector in Jinja, Uganda: Implications of Formalization and Regulation. African Studies Review 54(2): 73-93. Retrieved from http://www.jstor.org/stable/41304776.

Lloyd Jones, T., Dasgupta, N., Miles, N., Koojo, C.A., Majale, M., Porter, G., Roberts, M., Nunez Ferrera, I. and Redin, F. (2016) Transformational Change in Sub-Saharan Cities: the Role of Informality in the Hybrid Economy of Uganda. Research Monograph (Draft). Cities Alliance. In: http://www.citiesalliance.org/node/6138

Loayza, N. (1997) The Economics of the Informal Sector: A Simple Model and some empirical evidence from Latin America. Policy Research Working Paper 1727. Washington DC: World Bank. In: http://documents.worldbank.org/curated/en/685181468743710751/Theeconomics-of-the-informal-sector-a-simple-model-and-some-empirical-evidence-from-LatinAmerica

Lucas, R. (1988) On the Mechanics of Economic Development. Journal of Monetary Economics 22(1): 3-42. doi: 10.1016/0304-3932(88)90168-7.

McGee, T.G. (1971) The Urbanization Process in the Third World. London: Collins 
Educational.

McGee, T.G. (1967) Southeast Asian City: A Social Geography of the Primate Cities of Southeast Asia. First Edition. London: G. Bell \& Sons.

McMillan, M.S. and Rodrik, D. (2011) Globalisation, Structural Change and Productivity Growth. NBER Working Paper N 17143, June. NBER Programme. In: http://www.nber.org/papers/w17143.pdf.

Meagher, K. (2001) Book Review: Congo-Paris transnational traders on the margins of law by MacGaffey, J. and Bazengfuissa-Ganga, R. African Affairs 100(398): 152-154.

Mitullah, W., Stecj, J.F. and Dubresson, A. (2013) Africa Strategy Background Paper. Cities Alliance.

Moreno-Monroy, A. (2012) Critical Commentary. Informality in Space: Understanding Agglomeration Economies during Economic Development. Urban Studies 49(10): 20192030. doi: $10.1177 / 0042098012448554$

Moser, C. (1994) The Informal Sector Debate. In C. Rakowski (ed) Contrapunto The Informal Sector Debate in Latin America. Albany: State University Press of New York.

Moser, C. and Marsie-Hazen, J. (Eds) (1984) A survey of Empirical Studies in Industrial and Manufacturing Activities in the Informal Sector in Developing Countries. Viena: United Nations Industrial Development Organization.

Mukherjee, D. (2009) Informal sector in Indian economy: The Way Ahead. Delhi: Rawat Publications. 
NSSO (2006) Employment-Unemployment Situation in India 2004 - 2005, Round 61st , Report No. 515 - I and II (61/10/1\&2). New Delhi: Ministry of Statistics and Program Implementation. Government of India. In:

https://casi.sas.upenn.edu/sites/casi.sas.upenn.edu/files/iit/515part1_employment.pdf

Negroponte, N. (1996) Being Digital. New York: Random House.

New Vision (2014) Uganda to have a minimum wage by July 2015. New Vision, 9 June. In:

http://www.newvision.co.ug/new vision/news/1341532/uganda-minimum-wage-july-

2015\#sthash.e8BmGe1O.dpuf [Accessed 23 May 2016].

Nnkya. T. (2006) An Enabling Framework? Governance and Street Trading in Dar es Salam, Tanzania. In A. Brown (ed) Contested space: Street Trading, Public Space and Livelihoods in Developing Cities. Intermediate Technology Publications.

Nutz, N. \& Sievers, M. (2015) A Rough Guide to Value Chain Development. How to create employment and improve working conditions in targeted sectors. Second edition. Geneva: ILO.

Page, J. (2015) Foresight Africa: Top Priorities for the Continent I 2016. NY: Global Economy and Development, Brookings Institute. In: https://www.brookings.edu/wpcontent/uploads/2016/01/foresightafrica2016 fullreport.pdf.

Peattie, L. (1980) Anthropological perspectives on the concepts of dualism, the informal sector, and marginality in developing urban economies. International Regional Science 5: 131. doi: $10.1177 / 016001768000500101$. 
Portes, A. and Schauffer, R. (1993) Competing Perspectives on the Latin American Informal Sector. Population and Development Review 19(1): 33-60.

Potts, D. (2008) The Urban Informal sector in Sub-Saharan Africa: from bad to good and (back again). Development Southern Africa 25(2): 151-167. doi: 10.1080/03768350802090527.

Potts, D. (2007) City Life in Zimbabwe at a Time of Fear and Loathing: Urban Planning, Urban Poverty and Operation Murambatsvina. In Myers, G.and Murray, M. (eds.) Cities in Contemporary Africa. New York: Palgrave Macmillan.

Rakodi, C. and Lloyd-Jones, T. (2002) Urban Livelihoods: A People-centred Approach to Reducing Poverty. London: Earthscan.

Rogerson, C, M (1996) Urban poverty and the informal economy in South Africa's heartland. Environment \& Urbanisation, 8(1): 167-179. doi: 10.1177/095624789600800115.

Rolfe, R., Woodward, D., Ligthelm, A. and Guimaraes, P. (2010) The Viability of Informal Micro-Enterprises in South Africa. Paper at 'Entrepreneurship in Africa' conference, Syracuse University, New York. April 1-3, 2010.

Romer, P. (1990) Endogenous Technological Change. Journal of Political Economy 98(5): s71-s102.

Rakowski, C. (1994) The Informal Sector Debate, Part 2: 1984- 1993. In Rakowski, C. (ed.) Contrapunto: The Informal Sector Debate in Latin America. Albany: State University Press of New York

Santos, M. (1971) Les Villes Du Tiers Monde. Librairies Techniques, Paris. 
Schneider, F. and Enste, D. (2000) Shadow Economies around the World. Size, Causes and Consequences. IMF Working Paper 00/26. Washington DC: IMF. In: https://www.imf.org/external/pubs/ft/wp/2000/wp0026.pdf.

Sen, P. and Kolli, R. (2009) Delhi Group on Informal Sector - Contribution and Present Status. Paper Prepared for the Special IARIW-SAIM Conference on "Measuring the Informal Economy in Developing Countries”. Kathmandu, Nepal, September 23-26, 2009.

Sethuraman, S.V. (1981) The Urban Informal Sector in Developing Countries: Employment, Poverty and Environment. Geneva: ILO

Skinner, C. (2008) Street Trade in Africa: A Review. WEIGO Working Paper No 5. Cambridge, USA.

Tanaka, V. (2010) The 'Informal sector' and the political Economy of Development. Public Choice 145(1): 295-317. doi: 10.1007/s11127-009-9567-z

Tibaijuka, A. (2005) Report of a Fact Finding Mission to Zimbabwe to Assess the Scope and Impact of Operation Murambatsvina. United Nations. In: www.un.org/News/dh/infocus/zimbabwe/zimbabwe_rpt.pdf Todaro, M.P. (1969) A Model of Labor Migration and Urban Unemployment in Less Developed Countries. The American Economic Review 59(1): 138-148.

UBOS (2014) Uganda National Household Survey 2012/2013. Kampala: Uganda Bureau of Statistics. In: http://www.ubos.org/onlinefiles/uploads/ubos/UNHS_12_13/2012_13\%20UNHS\%20Final\% 20Report.pdf. 
UBOS (2012) 2012 Statistical Abstract. Kampala: Uganda Bureau of Statistics. In: http://www.ubos.org/onlinefiles/uploads/ubos/pdf\%20documents/2012StatisticalAbstract.pdf.

UBOS (2010) Uganda National Household Survey 2009/2010. Kampala: Uganda Bureau of Statistics. In:

http://www.ubos.org/onlinefiles/uploads/ubos/UNHS0910/UNHS\%20SOCIO\%20FINDINGS .pdf.

UNOPS (2015) Request for Proposal: Research \& coordination services for one project in Uganda. RFP No. RFP/CAC/FCA/E4C-Output2-Uganda/UNOPS/Sept2015.

Valodia, I and Devey. R. (2012) The Informal Economy in South Africa: Debates, Issues and Policies. The Journal of Applied Economic Research 6(2): 133-157. doi:

10.1177/097380101200600203.

WEIGO (2012) The Informal Economy: Definitions, Theories and Policies. Harvard: WEIGO Secretariat.

WIEGO (no date) Concepts, Definitions and Methods. Women in Informal Employment: Globalizing and Organizing. WIEGO. In: http://www.wiego.org/informaleconomy/concepts-definitions-methods

World Bank (1999) World Development Report 1999/2000: Entering the 21st Century. Washington DC: Oxford University Press. In: https://openknowledge.worldbank.org/handle/10986/5982 


\section{ENDNOTES}

${ }^{1}$ See for example Cleland and Machiyama (2016)

${ }^{2}$ One of the principal aims of DFID project was to set out an agenda for future study by the local and regional research community, including approaches that can be adopted in garnering.

${ }^{3}$ Interdisciplinary team of nine researchers, of whom seven were based in three UK universities and two in or associated with a specialist research and training agency in Uganda (see Lloyd Jones et al., 2016).

4 Peattie (1980) and Portes and Schauffer (1993) note that Hart's (Ibid) observation of the notable dynamics of the self-employed entrepreneurs, was lost in ILO's (Ibid) definition of the informal sector, which stressed the low barriers to entry in terms of skills and capital requirements; family ownership; outdated technology and unregulated and competitive markets.

${ }^{5}$ The World Bank programme in sub-Saharan Africa on behalf of the ILO, Un-Locking the Potential, (Grimm et al, 2011) and Nutz and Sievers (2015) emphasises the importance of increasing productivity of successful informal enterprises, to move them up the urban continuum. However, an approach that focuses on the enterprise and productivity can fail to address the knock on effects on women and the vulnerable, dependent on, and linked to these enterprises. An EU-funded project in Jinja, which aimed to upgrade the fishing sector, left behind the small fisherman, who did not have the capacity nor capability to participate in the project (Lince, 2011). Furthermore, Nnkya's (2002) work in Dar-es-Salaam shows that in the re-organisation of urban space, women were generally unable to access the more lucrative trading sites, as they were captured by the male traders. 